\section{SCHOLARS: Journal of Arts \& Humanities}

[Peer-Reviewed, Open Access Scholarly Publication] Indexed in NepJOL; JPPS Star-Ranked Journal

Print ISSN: 2773-7829; e-ISSN: 2773-7837

eJournal Site: www.cdetu.edu.np/ejournal/
Central Department of English

Tribhuvan University

Kirtipur, Kathmandu, Nepal

URL: www.cdetu.edu.np

Theoretical/Critical Essay Article

\title{
Dialectics of Trauma in the Short Stories of Alice Munro
}

\author{
Shruti Das, $\mathbf{P h D}^{1}$ \\ Deepshikha Routray, $\mathbf{P h D}^{2}$ \\ ${ }^{1}$ Department of English, Berhampur University, Odisha, India \\ ${ }^{2}$ Department of English, Maharishi College of Natural Law, Odisha, India
}

Article History: Submitted 10 June 2021; Revised 6 July 2021; Accepted 24 July 2021

Corresponding Author: Shruti Das, Email: drshrutidas@gmail.com

DOI: https://doi.org/10.3126/sjah.v3i2.39426

Copyright 2021 (C) The Author(s). The work is licensed under a Creative Commons Attribution 4.0 International License (CC BY 4.0).

\section{cc) (i)}

\begin{abstract}
This paper argues that difficult relationships in human life followed by memories, introspection, retrospection, foreshadow, flashback, and awful remembrances are coloured by pain and trauma. Unresolved trauma affects the way one perceives others and oneself in relation to others, which has a significant impact on relationships and often results in behaviour that is not conducive to healthy relationships. Complicated, disordered feelings and distressing emotions that give rise to anxiety find an expression in relationships, either overtly or covertly. This paper will focus on how the characters, suffering from anxiety due to stressed relationships, in the short stories in The Progress of Love, written by Alice Munro, employ defence mechanisms to repress their trauma and project a different version of themselves as responsible individuals who are capable of leading a normal life. The dialectic of trauma covertly present in the narrative will be unravelled using Judith Herman's theory of trauma. Further, this analysis will investigate and foreground how the underlying trauma finds indirect expression in complicated relationships.
\end{abstract}

Keywords: Dialectics of trauma, repression, anxiety, relationships, defence mechanisms

\section{Introduction}

Alice Munro has been writing short fiction since 1960 and has published more than eleven collections of short stories. She is the only short fiction writer from Canada to have received international acclaim. Although Alice Munro has denied having any interest in belonging to a literary tradition, her method of presentation, her narrative technique which intimately connects theme and underlying meaning, places her in the tradition represented by James, Joyce, Hemingway, and the other short fiction writers of the twentieth century. Stories are the medium to organise, predict and understand the complexities of our lived experiences. Alice Munro's The Progress of Love is a collection of short stories in which the wounds of the past affect the present relationships of the characters and an analysis of the complexities in their relationships, is an exploration of repressed 
trauma. The stories deal with choices made by people in their relationships and experiences of love. The Progress of Love is one of Munro's later collections. In this collection, she focuses on common individuals and their ability to continuously grapple with problems and try to find meaning. These individuals adjust their sensibilities in order to rise above their not-so-apparent traumatic experiences in everyday life. This paper will focus on how the characters, suffering from anxiety due to stressed relationships, in the short stories in The Progress of Love employ defence mechanisms to repress their trauma and project a different version of themselves as responsible individuals who are capable of leading a normal life.

Elissa Marder's explanation of indirect expression of trauma in literature highlights the importance of new ways of understanding and acknowledging the impact of traumatic events in one's life. In "Trauma and Literary Studies: Some 'Enabling Questions," she says that, "Literature is one of the ways we tell one another about aspects of human experience that cannot be contained by ordinary modes of expression and that may even exceed human understanding" (3). A similar contention is offered by Laurie Vickroy in Reading Trauma Narratives: The Contemporary Novel and the Psychology of Oppression when she states, "Literary renditions of trauma offer important insights into human responses to stress. They allegorize and reconstitute such experience through the narrators' or protagonists' words and their motivations by way of defensive coping strategies" (33). The experiences of trauma, represented often by the sense of helplessness felt by the victims remain unexpressed.

Judith Herman in the introduction to her book Trauma and Recovery has stated that "the conflict between the will to deny horrible events and the will to proclaim them aloud is the central dialectic of psychological trauma" (12). She argues that "The dialectic of trauma operates not only in the survivor's inner life but also in her close relationships. It results in the formation of intense, unstable relationships that fluctuate between extremes" (40). This argument of Herman forms the premise of this paper that will analyse the discourse in the stories of Munro to highlight the coping strategies and defence mechanisms adopted by Munro's characters in The Progress of Love to show how people cope up with the sense of guilt and helplessness that extensively damages their self-esteem and their desperate attempts to hold on to their unstable relationships. The stories taken for analysis in this paper are the title story 'The Progress of Love', 'White Dump', 'Monsieur Les Deux Chapeaux' and 'A Queer Streak'.

The psychological unacceptability often makes victims deflect attention from the pain that concerns their mental health. In order to protect themselves from feeling numb or suffer the pain of reliving the event, they make several attempts to dissociate themselves from it. To prevent the intrusion of others into their emotional space, trauma victims adopt coping strategies to camouflage their overwhelming mental states. Repression, denial, displacement, projection, sublimation, and regression are some of the defence mechanisms used by trauma victims to cope with the anxiety that results from unacceptable thoughts associated with an overwhelming experience. Repression as a defence mechanism involves "unconscious blocking of unpleasant emotions, impulses, memories, and thoughts from your conscious mind" (Cherry). Sublimation channels "negative and unacceptable impulses into behaviors that are positive and socially acceptable" (Cherry). The repeated attempts of the trauma victims, to strike a balance in their relationships in order to lead a socially acceptable life, are often subverted.

Commenting on the failure of trauma victims to find balance in their lives, Judith Herman has posited that,

This dialectic of opposing psychological states is perhaps the most characteristic feature of the posttraumatic syndromes. Since neither the intrusive nor the 
numbing symptoms allow for integration of the traumatic event, the alternation between these two extreme states might be understood as an attempt to find a satisfactory balance between the two. But balance is precisely what the traumatized person lacks. (47)

To understand the dialectics of trauma depicted in the representative stories of Alice Munro, taken for analysis in this paper, the body of the paper is divided into two seminal sections, namely, 'Intergenrational Trauma' and 'Trauma in Sibling Relationships.'

\section{Review of Literature}

A fair amount of critical analysis has been done on the work of Alice Munro, some of it has reduced Munro's stories to simple ideas and symbols and some critics have called stories realistic and commonplace dealing with love and marriage. In her essay "The Colonel's Hash Resettled," Munro responds to these literary critics, writing that such criticism makes her "gloomy," "angry," and "uneasy"; "Surely it's not that simple?" she reasons (181). Interestingly, a critic Tomasz Sikora in his article " "Shockingly Like, and Unlike, Home': Gothic Realism in The Progress of Love" analyses the stories in The Progress of Love from the point of view of gothic realism. He explores the notion of ambivalence in Munro's stories in line with Freud's essay "The Uncanny". Hui Gao in "Research on Marriage View in Alice Munro's Novels" posits that in Munro's work, the problems related to marriage are the most common subject.

Besides, it deals with the sense of selflessness and tolerance that women show in their marital relationships. The journey of life teaches the women the meaning of self and life, with a focus on the way they should develop control over their marriage and life. Francesconi in her article "Memory and Desire in Alice Munro's Stories" explores the discursive interconnections between memory and desire with a focus on the emotional component, self and narrative expression. However, the context of analysis broadened in Carol Beran's article "The Pursuit of Happiness: A Study of Alice Munro's Fiction" written in the year 2000, which deals with the theme of happiness in the stories of Munro based on four contexts: peace, order, liberty and religious and philosophical traditions. These contexts were based on Thomas Jefferson's declaration on the pursuit of happiness on July 4, 1776. The article focuses on the contemporary North American popular culture that considers happiness as an elusive ideal and mentions how conventional stories end with characters living happily ever after. Brenan borrows Thomas Jefferson's idea of the pursuit of happiness to analyse how happiness operates within Munro's stories. The emotional aspect of Alice Munro and A. L. Kennedy's short stories is analysed from the standpoint of Sara Ahmed's affect theory in Somacarrera's "“The Emotional Housekeeping of the World': Affect in Alice Munro's and A. L. Kennedy's Post-Millennial Short Stories". Ahmed highlights the shared belief of both the writers on new humanism in the context of the postcolonial spaces of their nation. Another addition to the study of Alice Munro's short stories is Lynn Blin "Sweet Dissonance in Alice Munro's 'The Progress of love,' 'Friend of My youth,' and 'Free Radicals", which brings out the way the grammatical characteristics of the introductory passages of Alice Munro's short stories reflect poignancy of pathos that offer a clue to the readers about that seeming dissonance that marks the development of her stories.

The complexities of the human psyche are further explored in Esmaeil Zohdi's "Alice Munro's 'Runaway' in the Mirror of Sigmund Freud" with a focus on the complex characterisation using the Freudian theory of unconscious along with his interpretation of dreams. Likewise, M.S. Chowdhury's article "Family Bond and Traumatic Pathology in Alice Munro's "The Bear Came Over the Mountain"” also critiques human relationships from a psychoanalytic point of view. Chowdhury shows 
"The Bear Came Over the Mountain" as a story of a relationship between unacquainted families and as an enigma of romance and psychological disorientation.

The focus on marriage and the man-woman relationship has often been explored in the critical works on Munro's short stories. It is pertinent to note from the review of a host of critical literature available that Munro's stories in the collection The Progress of Love have not been analysed with the lens of trauma theory with a special focus on the repressed memory and defence mechanisms adopted by the characters to camouflage their suffering and coping with life, which will form the premise of this article. Susan E. Babbitt suggests in her article "Stories from the South: A Question of Logic" that "stories themselves are not as epistemically significant as the questions that determine their meaningfulness in a specific context" (2). It is such significant questions that will determine the meaningfulness hidden in the pretentious behaviour of the characters in Munro's stories that this article will address.

\section{Intergenerational Trauma}

Intergenerational trauma began as a concept in trauma studies in 1966 after the Holocaust. Canadian psychiatrist Vivian M. Rakoff's documentation of psychological distress among the children of holocaust survivors and William Niederland's description of 'survivor syndrome' in 1968 was followed by extensive research on transgenerational effects of trauma. Later studies revealed that even healthy offspring of holocaust survivors can develop Post-Traumatic Stress Disorder. It is important to note that although the concept of intergenerational trauma emerged after much research addressing the psychological impact on the offspring of survivors of persecution and annihilation of the Jews by Nazi Germany, it is not restricted to it. It has expanded its horizon to study the collective distress of Native American Genocide survivors and the trauma of the African-Americans forced into slavery, to name a few. Several case studies reveal that transmission of trauma can be seen in anxiety and depressive disorders. Munro's title story in the collection The Progress of Love involves three generations of women dealing with the weight of the past. The story of psychological wounding moves from a woman named Euphemia, who is now divorced, to her mother Marietta and then to Marietta's mother. The incident where Marietta finds her mother in a barn with a noose tied around her neck attempting suicide forms the point of crisis in the study of intergenerational trauma in this story. When Marietta's mother passed away due to some sickness, her father remarried and moved away with her sister Beryl. Marietta was emotionally devastated that she never received the comfort she wanted from her father after her mother's death. Marietta's anxiety and frustration are manifested in her relationship with her daughter. Marietta burns the money she inherited from her father when that could have been used for Euphemia's education. This is a display of her anger and the subversive trauma she has been living with because of her father. This act of Marietta can be read as a trauma response transported unwittingly to her daughter Euphemia. It is the transportation of her feeling of anxiety and deprivation that she was made to silently suffer all her life. In spite of her underlying trauma, Marietta continues to tell people that her father supported her to hide the secrets of her family. Likewise, Euphemia, as her name suggests, tries to project her family in a positive light in a euphemistic manner despite her knowledge that her mother, Marietta, was planning to hire her out "to help women in the neighbourhood who were sick or having a baby" for money (8). Marietta doesn't allow Euphemia to go to high school although she had been a school teacher herself. Euphemia is unable to accept this harsh truth but by way of camouflaging the truth about the dark side of her mother says that "There was a cloud, a poison, that had touched my mother's life" (13). In fact, upon her mother's death, Euphemia says she became a part of that cloud (13). This is an affirmation of the 
transmission of trauma from mother to daughter. We find a repetition of the trauma when Euphemia is estranged from her husband.

Marriages are not shown as "happily ever after" in the stories of The Progress of Love. In almost all the stories in this collection, Munro depicts complex relations and their associated limitations, expectations, and fulfilment. Characters often exhibit unflinching devotion and dedication to relationships to make them appear successful. Betrayal is camouflaged under facades of fidelity. In the title story "The Progress of Love," the narrator fondly speaks of her father whom she treats solely as a family man. She says, ". . my father never slept with any woman before my mother, and never with her until he married her" (5). The narrator interestingly exposes that her mother did not marry until she had paid her father the entire amount, he spent on her since her mother died: " . . my mother wouldn't get married until she had paid back to her own father every cent he had spent on her since her mother died" (5). Thus the narrative subverts a filial relationship and points at the underlying trauma. Munro's portrayals of marriages as simple often belie the repression involved. Even divorces are treated normally as if "The Lord never intended" (5). Like the deliberate attempt made by the narrator to show blissful filial bonding, there is also a deliberate justification of the clean image of the father projected by the daughter when she insists that he was not a womaniser. All such attempts by the three generations of women in the story reflect an unconscious mental process to protect themselves from conflict, shame, and anxiety. This refers directly to Judith Herman's as defense mechanisms in psychoanalytical theory. Such mechanisms help a traumatised person to hide her vulnerability.

Another story, "White Dump," is about three generations of women- Denise, her mother, Isabel, and her grandmother, Sophie. The title "White Dump" derives from a childhood memory of Isabel where a "pure White mountain" of "quantities of vanilla icing and nuts and hardened marshmallow globs" were collected from the floors of a bakery and piled up near the school playground (306). Isabel and her friends, who were from "poor" families were magically drawn to the White Dump: "It was like a kid's dream - the most wonderful promising thing you could ever see" (306). Isabel detests being labelled a person from poor a family who fantasised about the white dump. Such resistance finds an unconscious presence in her relationships. Right from the beginning of the story, some conversations point towards a lot of things that they have discarded from their life long ago. The image of white dump that the children fantasise about is symbolic of the happy and clean relationships that everyone dreams of, which in reality is missing in the life of Denise, Isabel, and Sophie. Before a reader gets to know anything about their lives Denise tells her step-mother Magda, regarding their renovated home, that "I don't really remember any color in this house at all" (275). In fact, it is not the house that lacked colour but their lives that were colourless and dreary.

Denise tries to project herself as an emancipated woman even as she depends on her father's financial help for a Women's Centre she runs in Toronto. Her father Laurence is against "Helping those who won't help themselves" (277). He is of opinion that the women at the women's centre are "enjoying all the attention they are getting, claiming to be battered and raped, and so on" (276). Accepting financial help from a person who has such a demeaning opinion about women is generally unacceptable by any emancipated woman, contrarily Denise fights to get a cheque from her father for the women's centre. Laurence comments on the pretentious lifestyle maintained by Denise saying that, "this is typical pattern for a girl of affluent background" (276).

Denise's grandmother, Sophie too hides the truth concerning her life to project the image of an emancipated woman. Sophie has fought against odds when she gave birth to Laurence out of wedlock after falling in love with a married man. "She was too proud to 
ask him to uproot himself, leave his wife, follow her to the Log House, where she waited for Laurence to be born, but she believed that he must do so" (295). Even when

Laurence's father visited her, she preferred to talk about events from her childhood rather than the child she was going to give birth to. It is on an aircraft, during their flight on Laurence's fortieth birthday that she realised that she has been engulfed by her false pride. Her repressed feelings come to the fore during the flight. We read,

That toy like, perfect tininess of everything had a peculiar and distressing effect on Sophie. She felt as if it was, she, not the things on earth, that had shrunk, was still shrinking-or that they were all shrinking together. This feeling was so strong it caused a tingle in her now tiny, crablike hands and feet- a tingle of exquisite smallness, an awareness of exquisite smallness.

...This feeling-Sophie was realizing-wasn't new to her" and she calls it a "genuine shrinking feeling, one of the repertoires of frightening, marvellous feelings, or states, that are available to you when you're very young. Like the sense of hanging upside down, walking on the ceiling, stepping over heightened doorsills. (296)

Sophie's trauma was so overwhelming that she unconsciously repressed her trauma in order to safeguard her mind against emotions that she was unable to cope with. Like Sophie, who tries to repress her fears, anxiety and isolation to project herself as a strong emancipated woman, Isabel too, represses her feelings to project herself as a wonderful wife fulfilling all her duties in the best possible way without any conflict in her marriage. She lives a kind of mechanised existence, performing her duties as a mother and wife while trying her best to hide the fact that she was extremely disappointed in her marital relationship. She wanted to be left alone. According to Laurence, "Sitting by herself is my wife's greatest pleasure" (303). Her sitting by herself is not really isolation but the freedom from the pressure to sustain her relationship. The narrative subtly exposes her trauma, in that, she didn't want anybody to find out that she was "as cold at heart as that Old Norse Sophie" (303). What Isabel wanted was,

Freedom-or not even freedom. Emptiness, a lapse of attention. It seemed all the time that she was having to provide a little more-in the way of attention, enthusiasm, watchfulness-than she was sure she had. She was straining, hoping not to be found out. Found to be as cold at heart as that Old Norse, Sophie. (303)

Being cold at heart is a kind of emotional numbness that is considered as a trauma response to the external world according to the American Psychiatric Association. This cold response can be explained through the work of Anna Freud, The Ego and the Mechanisms of Defence, in which she emphasises that ego is unaware of the defence mechanism that takes place unconsciously. One of the defence mechanisms is intellectualization that reduces the anxiety when the victims think about it in a cold, dispassionate manner. The focus here is on the intellectual component rather than the emotional aspect (Cherry). Similarly, In Ego Mechanisms of Defence (1992) George E Vaillant notes,

Intellectualization refers to thinking as a limited variety of doing- as a mode of controlling affects and impulses by thinking them instead of experiencing the feelings associated with them. The person employing intellectualization uses the thinking process defensively, as a substitute for and protection against emotion and impulse. As a result, he or she emphasizes reason, devoid of affect, and tends to give blandly abstract, esoteric, or logical explanations of internal and external conditions. (274)

Trauma changes one's emotional response as well as relationship pattern that can be observed in the psychological defence mechanisms employed by the characters in Munro's stories to project a different version of themselves that is normative of society. 
All the three women: Denise, Isabel, and Sophie lead a pretentious life putting in their best efforts to confirm. The last line of the story, which is a verse read by Isabel, aptly expresses the fact that the women had resigned to their fate: "It is too late to talk of this now: it has been decided" (309). The discourse shows their sense of resignation that they are destined to lead traumatic lives as women treading the beaten path. Like the white dump, they want to hide the dark aspects of their life and pretentiously whitewash their suffering by repressing it.

\section{Trauma in Sibling Relationships}

Denial is a human instinct that protects us and helps us evade hurt, dissociates us from the painful event and represses the memory of the trauma. The symptoms of unresolved trauma may include, among many others, addictive behaviours, and an inability to deal with conflict, anxiety, confusion, depression exhibiting an innate belief that we have no value. The most representative story in The Progress of Love is "Monsieur Les Deux Chapeaux" which depicts the relationship of two brothers, the stable and responsible Colin, and his odd and vulnerable younger brother, Ross. Colin, as a young boy, had nearly shot and killed Ross, accidentally, while playing with a rifle. Shortly after discovering that he had, in fact, not killed his brother, Colin comes to realise that he has to "watch out for something like that happening - to Ross, and to himself - was going to be his job in life from then on" (83). Dual personality plays an important role in "Monsieur Les Deux Chapeaux," which is shown in the characterization of Ross. The presence of dual personality within Ross complicates his relationship with others, especially, his brother Colin. Ross likes to do weird activities and spring surprises on everyone. The two different hats that he puts on indicate the manner of his thinking and the way he perceives life. According to E. D. Blodgett, "The two hats symbolize Ross's two roles, his public and private ones, and explain in a certain measure the difficulty of his relationship with his brother Colin" (137). Ross's behaviour was quite unstable, reckless, and unfathomable. He is hilarious sometimes and dangerous at other times. Ross manifests the strangeness of his inner mind. He does not hesitate to wear his mother's blond wig to the supermarket. He had also misbehaved and stalked a teenage girl in the ninth standard so much so that she was forced to "to hiding in the girls' washroom," then ultimately "dropped out of school altogether and married at seventeenth" because "Ross was too much for her" (62). Colin attempts to hide his brother's eccentricities because of the promise he had made to himself after the traumatic event when he nearly killed his brother as a child. His defensiveness towards Ross is a strategy to cope, to hold on to his relationship, and show that everything is alright. The shooting incident remains forever embedded in his memory. The horror that he experienced years back revisits him time and again, he exclaims that "It was as painful as fiery blood pushing into frozen parts of your body" (83).

The complicated relationship between siblings is further explored in the story "A Queer Streak". Violet, the protagonist in this story, is somewhat similar to Colin, in that she feels the need to look after her younger sisters, particularly her emotionally unstable sister Dawn Rose. At a tender age, Violet started looking after her sisters. She makes it to the Normal School to train as a teacher. But this is not to be as she has to leave behind her training and come back to her family to manage the home. She stakes, her career, love, and future to save her family, especially her psychologically unstable sister Dawn Rose. Later in life, Violet is troubled by the sense of loss and isolation as her sister, who now has a family of her own and doesn't quite care about Violet. Violet's life becomes a tragedy. Overwhelmed by her sense of isolation she drives into a ditch. She escapes from the spot when her car falls into the ditch so that she would not be blamed: "But when she 
did hear a car moving, she knew she didn't want to be found. She couldn't bear to be. She ran from the road into the woods ... Hiding because she didn't want to be seen, if her life was tragic" (234). Violet's escape and being sighted in a bush in the woods can aptly be considered as a trauma response to the sense of isolation and loss she grapples with. Her situation is described thus: "Her whole life was being pulled away from her her future, her love, her luck, and her hopes. All that was being pulled off like skin, and hurt as much, and left her raw and stinging" (231). In the end, when Violet passes away in a hospital, we are told that it is, "A delayed reaction, perhaps. Shock" (252). E. D. Blodgett in her book Alice Munro observes that the ditch is "an image and symbol of her tragic situation" (140). All these images justify Judith Herman's statement that "Traumatic memories lack verbal narrative and context; rather, they are encoded in the form of vivid sensations and images" (38).

Munro has stated in an interview published in Canadian Fiction Magazine that "Mostly in my stories I like to look at what people don't understand. What we don't understand. What we think is happening and what we understand later on, and so on" (qtd. in Howells 69). Her statement can be read as an indirect representation of the repressed feelings that torment the characters in her stories.

\section{Conclusion}

The stories analysed above reiterate the argument of Judith Herman in Trauma and Recovery where she states,

Trauma impels people both to withdraw from close relationships and to seek them desperately. The profound disruption in basic trust, the common feelings of shame, guilt, and inferiority, and the need to avoid reminders of the trauma that might be found in social life, all foster withdrawal from close relationships. But the terror of the traumatic event intensifies the need for protective attachments. The traumatized person therefore frequently alternates between isolation and anxious clinging to others. The dialectic of trauma operates not only in the survivor's inner life but also in her close relationships. It results in the formation of intense, unstable relationships that fluctuate between extremes. (56)

The unstable relationships explored in the selected stories in The Progress of Love justify by example what Judith Herman has theorized as dialectics of trauma. All these stories bring to fore how the defence mechanisms used by characters in the face of traumatic experiences have a negative impact on their relationships within their families and in society. Consequently, the characters lead a mechanised and repressed existence. In all four stories analysed in this paper, whether it is the relationship between siblings, marital relationships, or the relationship that the seemingly independent and emancipated women have with their families, the struggle is to obtain social acceptability. Some of the characters are able to justify their actions while others fail to even acknowledge the pain they are suffering. Sometimes, the characters resort to fantasy in order to substitute the imaginary for the real situations. Faced with the dialectics of trauma, the characters in the stories of Munro's The Progress of Love, like real-life humans, employ mechanisms to leave the scene of conflicts psychologically.

\section{Works Cited}

Babbitt, Susan E. "Stories from the South: A Question of Logic." Hypatia, vol. 20, no. 3, 2005, pp. 1-21., https://doi:10.1111/j.1527-2001.2005.tb00484.x.

Beran, Carol L. "The Pursuit of Happiness: A Study of Alice Munro's Fiction." The Social Science Journal, vol. 37, no. 3, 2000, pp. 329-345., https://doi:10.1016/s0362-3319(00)00072-0. 
Blin, Lynn. "Sweet Dissonance in Alice Munro's 'The Progress of love,' 'Friend of My youth,' and 'Free Radicals." 2015. Commonwealth Essays and Studies, vol. 37, no. 2, Société d'Étude des Pays du Commonwealth, 2015, pp. 45-55, https://search.informit.org/doi/10.3316/informit.355260424572.

Blodgett, E. D. Alice Munro. Twayne Publishers, 1988.

Geoffrey Hancock, "An Interview with Alice Munro" Canadian Fiction Magazine, 43, 1982, p. 90.

Cherry, Kendra. "Common Defense Mechanisms People Use to Cope with Anxiety." Verywell Mind, 15 Feb. 2021, http://www.verywellmind.com/defensemechanisms-2795960.

---. "How Does Sublimation Influence Your Behavior?" Verywell Mind, Dotdash, 2020, www.verywellmind.com/what-is-sublimation-in-psychology-4172222.

---. "How Does Repression Work in Our Unconscious Mind?" Verywell Mind, Dotdash, 2021, www.verywellmind.com/repression-as-a-defense-mechanism-4586642.

Chowdhury, Mohammad Shahidul. "Family Bond and Traumatic Pathology in Alice Munro's "The Bear Came Over the Mountain." Stamford Journal of English, vol. 6, 2013, pp. 103-113., https://doi:10.3329/sje.v6i0.13906.

Francesconi, Sabrina. "Memory and Desire in Alice Munro's Stories." Textus, XXII, 2009, pp. 341-360.

Gao, Hui. "Research on Marriage View in Alice Munro's Novels." 2017 4th International Conference on Literature, Linguistics and Arts (ICLLA 2017), 2017, pp. 138-141., https://doi:10.25236/iclla.2017.32.

Howells, Coral Ann. Alice Munro. Kiribati, Manchester University Press, 1998.

Munro, Alice. The Progress of Love. Vintage Books, 1986.

-----. "The Colonel's Hash Resettled." The Narrative Voice: Stories and Reflections by Canadian Authors. Ed. John Metcalf. McGraw-Hill Ryerson, 1972, pp. 181-183.

Niederland, William G. "The Survivor Syndrome: Further Observations and Dimensions." Journal of the American Psychoanalytic Association, vol. 29, no. 2, Apr. 1981, pp. 413-425, https://doi:10.1177/000306518102900207.

Portney, Charles. "Intergenerational Transmission of Trauma: An Introduction for the Clinician." Psychiatric Times, 1 Apr. 2003, www.psychiatrictimes.com/view/intergenerational-transmission-traumaintroduction-clinician.

Sikora, Tomasz. "'Shockingly Like, and Unlike, Home': Gothic Realism in the Progress of Love.” Alice Munro, 2016, pp. 49-64., doi:10.1007/978-3-319-24061-9_5.

Somacarrera, Pilar. "'The Emotional Housekeeping of the World': Affect in Alice Munro's and A. L. Kennedy's Post-Millennial Short Stories." The Journal of Commonwealth Literature, vol. 55, no. 2, 2018, pp. 309-325., https://doi:10.1177/0021989418807241.

Vaillant, George E. Ego Mechanisms of Defense: A Guide for Clinicians and Researchers. American Psychiatric Press, 1992.

Zohdi, Esmaeil. "Alice Munro's 'Runaway' in the Mirror of Sigmund Freud." International Journal of Applied Linguistics \& English Literature, vol. 4, no. 2, 2014, https://doi:10.7575/aiac.ijalel.v.4n.2. p. 169. 